\title{
PROFITABILITY ANALYSIS OF BAGDA FARMING IN SOME SELECTED AREAS OF SATKHIRA DISTRICT
}

\author{
A. N. M. Wasim Feroz ${ }^{1}$, M. H. A. Rashid ${ }^{2}$ and Mahbub Hossain ${ }^{3}$ \\ Department of Agricultural Economics, Bangladesh Agricultural University \\ Mymensingh 2202, Bangladesh
}

\begin{abstract}
This study aimed at examining the relative profitability of shrimp production in some areas of Satkhira district. Farm level data were collected through interviewing 60 randomly selected farmers. Mainly tabular analysis was done to achieve the major objectives of the study. Cobb-Douglas production function was used to estimate the contribution of key variables to the production process of shrimp farming. Analysis of costs and returns showed that per hectare total cost of shrimp production was Tk. 1,06,791.00 and net return from shrimp production was Tk. 84,023.80. Production function analysis proved that inputs such as fry, human labour, fertilizers, manure, lime etc. had positive impact on output. The study also identified some problems and suggested some possible steps to remove these problems. If these problems could be solved bagda production would possibly be increased remarkably in the study area as well as in Bangladesh.
\end{abstract}

Key words : Year-round bagda farming, Profitability, Functional analysis

\section{INTRODUCTION}

Agriculture sector contributes 21\% (BER, 2008) to the Gross Domestic Product (GDP) of Bangladesh economy as a whole of which fisheries sector's share is $4.73 \%$. Shrimp farming and related activities contribute significantly to the national economy of Bangladesh. The main areas of contribution are export earning and employment generation through on farm and off-farm activities. Bangladesh has about 2.5 million hectares of coastal tidal land under brackish water culture. Besides shrimp farming area is steadily expanding. But most of the farmers still follow the traditional method and per unit production is very low $(150-250 \mathrm{~kg} / \mathrm{ha})$. As a result, production cost is higher compared to other shrimp growing countries of the world.

In Bangladesh, fish provides 63 percent of animal protein consumption and about 1.2 million people are directly employed in this sector. Another 10.8 million people indirectly

\footnotetext{
${ }^{1}$ Post-graduate Students, Department of Agricultural Economics, Bangladesh Agricultural University Mymensingh-2202, Bangladesh

2 Professor, ${ }^{3}$ Lecturer, Department of Agricultural Economics, Bangladesh Agricultural University Mymensingh-2202, Bangladesh
} 
earn their livelihood out of activities related to fisheries (FFYP, 1997 - 2002). The fisheries sector contributes $4.73 \%$ of gross domestic products (GDP) and about $4.04 \%$ to foreign exchange earning through export (BER, 2008 and FSYB 2007 - 08).

The annual growth rate of fish production was 5.05 percent in the year $2007-2008$ which was greater than what it was in 2006 - 2007 but lower than 2005 - 2006 (FSYB, 2007 - 2008). The country earned about Tk. 33,962.80 million foreign currencies during 2007-2008 by exporting fish and shrimp, of which shrimp alone contributes Tk. 28,639.20 million (FSYB, 2007 - 2008). However, fish production in Bangladesh was lower compared to that of other fish producing countries.

In Bangladesh, brackish water shrimp (Penaeus monodon) farming is currently one of the most important sectors of the national economy. Within the overall agro-based economy of the country, the contribution of shrimp production has been considered to hold good promise of creating jobs and earning foreign currency. The brackish water shrimp, locally known as bagda, is a highly valued product for international markets. Almost all shrimps are therefore exported, particularly to the USA, Japan and Europe. Brackish water shrimp farming is mostly concentrated in southern Bangladesh mainly Satkhira, Cox's Bazar, Khulna and Bagerhat districts. In southern Bangladesh, thousands of farmers have converted their paddy fields to 'gher' to accommodate a profitable shrimp culture practice.

Bagda farming should receive an attention in order to earn huge amount of foreign currency for the increasing population of Bangladesh. Presently, government and nongovernment organizations are extending scientific method of shrimp production. There exist wide variations in the yield of shrimp under different cultural and management practices of shrimp farming. In order to increase the production of shrimp farming to the maximum possible extent, it is necessary to identify the factors behind the yield variations so that policy interventions may be made accordingly. With this end in view, this study was undertaken to achieve the following objectives:

i. to determine the costs and returns of bagda farming;

ii. to identify the factors affecting yield and economic returns; and

iii. to suggests some policy guidelines/recommendations.

\section{MATERIALS AND METHODS}

\section{The data}

Data for the present study was collected from sixty randomly selected bagda farmers of three villages namely : Assasuni, Manik-Khali and Durgapur of Assasuni upazila of Satkhira district. 


\section{Analytical technique}

Data were analyzed with the purpose of fulfilling the objectives of the study. In this study the following two techniques of analysis were used :

\section{Tabular technique}

The tabular technique of analysis was used to determine the cost, returns and profitability of farm enterprises. It is simple in calculation, widely used and easy to understand. It was used to get the simple measures like average, percentage and ratio. Tabular technique included production practices and input use, cost and returns of bagda farming.

\section{Statistical technique}

The input-output relationships in bagda farming under different farming systems were analyzed with the help of Cobb-Douglas production function approach. To identify the combination of most important variables in the production process of bagda shrimp, the following specification of the model was used.

$\mathrm{Y}=\mathrm{a} \mathrm{X}_{1 \mathrm{i}}{ }^{\mathrm{b} 1} \mathrm{X}_{2 \mathrm{i}}{ }^{\mathrm{b} 2} \mathrm{X}_{3 \mathrm{i}}{ }^{\mathrm{b} 3} \mathrm{X}_{4 \mathrm{i}}{ }^{\mathrm{b} 4} \mathrm{X}_{5 \mathrm{i}}{ }^{\mathrm{b} 5} \mathrm{X}_{6 \mathrm{i}}{ }^{\mathrm{b} 6} \mathrm{X}_{7 \mathrm{i}}{ }^{\mathrm{b} 7} \mathrm{X}_{\mathrm{e}}^{\mathrm{U}}$

The Cobb-Douglas production function was transformed into following logarithmic form so that it could be solved by ordinary least squares (OLS) method.

$\ln Y=\ln a+b_{1} \ln X_{1}+b_{2} \ln X_{2}+b_{3} \ln X_{3}+b_{4} \ln X_{4}+b_{5} \ln X_{5}+b_{6} \ln X_{6}+b_{7} \ln X_{7}+U$

Here,

$\mathrm{Y}=$ Gross income from year round bagda farming (Tk/farm)

$\mathrm{X}_{1}=$ Cost of Urea $(\mathrm{Tk} / \mathrm{ha})$

$\mathrm{X}_{2}=$ Cost of TSP (Tk/ha)

$\mathrm{X}_{3}=$ Cost of manure $(\mathrm{Tk} / \mathrm{ha})$

$\mathrm{X}_{4}=$ Cost of human labor $(\mathrm{Tk} / \mathrm{ha})$

$\mathrm{X}_{5}=$ Cost of lime $(\mathrm{Tk} / \mathrm{ha})$

$\mathrm{X}_{6}=$ Cost of bagda fry (PL) (Tk/ha)

$\mathrm{X}_{7}=$ Fin fish fingerlings cost $(\mathrm{Tk} / \mathrm{ha})$

$\mathrm{a}=$ Intercept

$\mathrm{b}_{\mathrm{i}}=$ Production coefficient and

$\mathrm{i}=1,2,3, \ldots . ., 7$

\section{Profitability analysis}

Cost and return analysis is the most common method of determining and comparing the profitability of different farm household or technologies. Profit is defined as the difference between the total revenue and total cost. The following conventional profit equation was applied to examine farmers' profitability level of the shrimp producing farms in the study areas.

Net profit,

$\pi=\sum_{i=1}^{n}$ Psb. $\theta . s b+\sum_{i=1}^{n}$ Pof. $\theta o f-\sum_{i=1}^{n}$ Pxi.Xi - TFC 
Where,

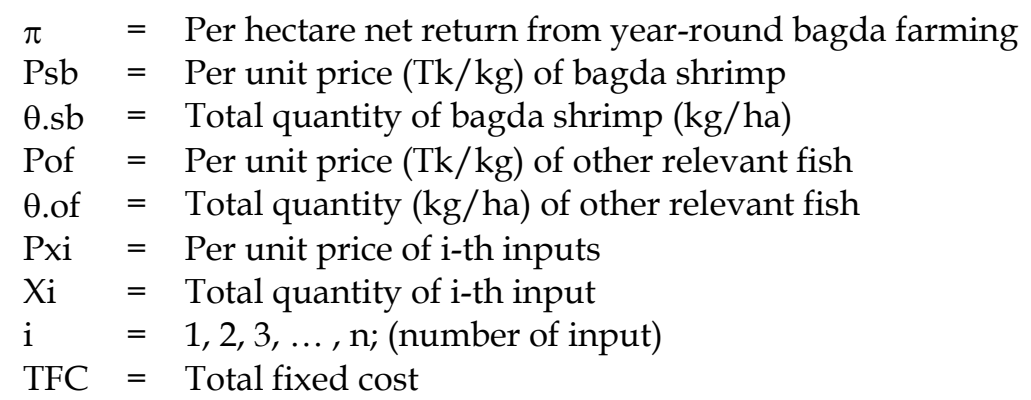

\section{RESULTS AND DISCUSSION}

\section{Estimation of costs and returns}

\section{Total variable cost (TVC)}

Costs and returns were considered from farmers' point of view. Variable cost for year round bagda shrimp farming, calculated considering family supplied and purchased inputs, was Tk. 57,171.00 per hectare (Table 1). From the Table 1, we can see that the highest portion of the total variable costs was contributed by cost of bagda fry which was about $42 \%$ of the total variable costs. The next highest cost of year round bagda farming was human labour cost which was about $29 \%$ of total variable costs. The rest of cost items i.e., cost of lime, cost of fertilizer and manure, cost of fin fish fingerlings, miscellaneous and interest constitute the remaining $29 \%$ of total variable costs. Among the variable costs, manure occupies the smallest portion which is only $0.87 \%$.

Table 1. Per hectare variable cost of year round bagda farming

\begin{tabular}{r|l|c|c|c|c|c}
\hline $\begin{array}{r}\text { Sl. } \\
\text { No. }\end{array}$ & Variable cost items & Units & Quantity & $\begin{array}{c}\text { Price/Unit } \\
(\mathrm{Tk})\end{array}$ & Cost (Tk) & \% of total \\
\hline 1 & Human labor & Man-days & 150 & 110 & 16500 & 28.86 \\
2 & Shrimp fry (PL) & Numbers & 59840 & 0.40 & 23936 & 41.87 \\
3 & Lime & $\mathrm{Kg}$ & 100 & 10 & 1000 & 1.75 \\
4 & Urea & $\mathrm{Kg}$ & 150 & 12 & 1800 & 3.15 \\
5 & TSP & $\mathrm{Kg}$ & 80 & 35 & 2800 & 4.90 \\
6 & Manure (cow dung) & $\mathrm{Kg}$ & 1000 & 0.50 & 500 & 0.87 \\
7 & Fin fish fingerlings & $\mathrm{Kg}$ & 40 & 110 & 4400 & 7.70 \\
8 & Miscellaneous cost & - & - & - & 2000 & 3.50 \\
9 & Interest on operating capital (OC) & - & - & - & 4235 & 7.41 \\
& Total variable cost (TVC) & - & - & - & 57171 & 100 \\
\hline
\end{tabular}

Source : Field survey 2009 


\section{Total fixed cost (TFC)}

Per hectare fixed cost for year- round bagda farming was Tk. 49,620.00 (Table 2) of which land use cost constitutes about $91 \%$, construction of infrastructure and canal digging contributed about 4.5 and $3 \%$ respectively.

Table 2. Per hectare fixed costs of year round bagda production

\begin{tabular}{|c|c|c|c|}
\hline Sl. No. & Cost items & Cost Tk/ha & $\%$ of total \\
\hline 1. & Land use cost & 44880 & 90.45 \\
\hline 2. & $\begin{array}{l}\text { Construction of water supplying canal, sluice guard, office and } \\
\text { other housing cost }\end{array}$ & 2244 & 4.52 \\
\hline 3. & Canal digging and dyke & 1496 & 3.01 \\
\hline 4. & Miscellaneous & 1000 & 2.02 \\
\hline & Total fixed costs, TFC & 49620 & 100 \\
\hline
\end{tabular}

\section{Total cost (TC)}

The total costs were calculated by adding up total variable cost and total fixed cost. Per hectare total cost of year-round bagda production for the selected areas was Tk. 1,06,791.00.

\section{Economic return of year-round bagda farming}

In this section, year-round bagda shrimp farming in terms of per hectare yield, gross income and net return are discussed. Therefore, the economic return of producing yearround bagda shrimp was calculated from the standpoint of farmers. All the returns were accounted for study period.

\section{Gross income}

Gross income is the pecuniary value of total product. Per hectare gross incomes were calculated by multiplying the total amount of production by their respective market prices. In the study areas, per hectare average yield of shrimp was $433.84 \mathrm{~kg}$ and its monetary value was Tk. 1,57,977.60. Apart from this, few species of shrimps and fishes, as indicated above, were also grown in shrimp farms. Therefore, the gross income for year round bagda farming was Tk. 1,90,814.80.

\section{Net return and relative profitability of year-round bagda shrimp farming}

Net return is the difference between gross income and the total cost of production. Per hectare total cost, gross income and net return of bagda shrimp are presented in Table 3. It may be noted here that per unit price of bagda shrimp varies depending on the transportation and marketing systems and size of individual grades of bagda shrimp. Per hectare total cost, gross income and net return were Tk. 1,06,791.00, Tk. 1,90,814.80 and Tk. $84,023.80$ respectively (Table 3 ). 
Table 3. Per hectare economic return of year-round bagda farming

\begin{tabular}{lccccc}
\hline \multicolumn{1}{c}{ Items } & Yield (kg/ha) & Price & Gross income (Tk/ha) & \% of gross income \\
\hline (i) Bagda shrimp & \multicolumn{5}{c}{} \\
$\quad$ A-grade & 44.88 & 560 & 25132.80 & 13.17 \\
B-grade & 149.60 & 440 & 65824.00 & 34.50 \\
C-grade & 239.36 & 280 & 67020.80 & 35.12 \\
(ii) Tilapia & 127.16 & 40 & 5086.40 & 2.67 \\
(iii) Pershey & 37.40 & 180 & 6732.00 & 3.52 \\
(iv) Horina & 29.92 & 200 & 5984.00 & 3.14 \\
(v) Chali & 22.44 & 130 & 2917.20 & 1.53 \\
(vi) Tangra & 52.36 & 160 & 8377.60 & 4.59 \\
(vii) Vetki & 14.96 & 250 & 3740.00 & 1.96 \\
Gross income & - & - & 190814.80 & 100 \\
Total cost (TVC+TFC) & - & - & 106791.00 & \\
Net income & - & - & 84023.80 &
\end{tabular}

Own calculation

\section{FACTORS AFFECTING YIELD AND ECONOMIC RETURNS OF BAGDA SHRIMP FARMING}

\section{Functional analysis for measuring production efficiency}

Two forms of production function model were initially estimated to determine the effect of variable inputs. Seven inputs or explanatory variables were hypothesized to explain the year-round bagda farming in the study areas. Finally, regression analysis (ordinary least squares method) was used to determine the effect of these inputs.

Management factor was not included in the model because specification and measurement of management factor is almost impossible particularly in the present study, where a farm operator is both a labor and manager. Other independent variables like water quality, soil condition, time etc., which might have affected production of farm enterprises were excluded from the model on the basis of some preliminary estimation.

A brief description is presented here about the explanatory variables included in the model.

\section{Interpretation of results}

Estimated values of the coefficients and related statistics of Cobb-Douglas production function for the selected sample farmers producing bagda shrimp are presented in Table 4. The following features emerged: 
The coefficient of multiple determinations $\mathrm{R}^{2}$ for bagda farming was 0.978 which indicates that $97.8 \%$ of the total variation of output of respective farming system is explained by independent variables included in the model.

F-value is highly significant implying that all the included explanatory variables are important for explaining the variation of year-round bagda farming. Therefore, $t$-values of the individual coefficients should be expected to be significant.

The relative contribution of specified factors affecting productivity of bagda farming can be seen from the estimates of regression equation. In total, there are seven input coefficients for the production of bagda and only one coefficient had improper (negative) sign and the remaining coefficients showed positive effect on farm output. In case of bagda shrimp farming, urea, manure, human labour and lime had proper (positive) sign.

Cost of Urea $\left(\mathbf{X}_{1}\right)$ : Cost of using urea was significant and had positive effect on farm income as indicated by its coefficient. Other factors remaining constant, $1 \%$ increase in cost of using urea would increase income by $0.109 \%$ for bagda farming.

Cost of TSP $\left(\mathbf{X}_{2}\right)$ : The production coefficient of TSP $(0.045)$ was significant at 10 percent level for bagda farming. It indicates that $1 \%$ increase of TSP, remaining others factors constant, would increase gross income by $0.045 \%$.

Cost of manure $\left(\mathbf{X}_{3}\right)$ : In year-round bagda farming the coefficient of cost of manure was 0.218 which indicates that there is enough scope to increase the gross income per hectare by spending additional amount on manure. An increase of $1 \%$ money spent on manure, keeping other factors constant, would result in an increase of gross income by $0.218 \%$.

Cost of human labor $\left(\mathbf{X}_{4}\right)$ : Estimated coefficients of human labour were significant for bagda farming. This implies that $1 \%$ increase in the cost of human labour as additional expenditure, remaining other factors constant, would increase gross returns by $0.220 \%$, for year-round bagda farming.

Cost of lime $\left(X_{5}\right)$ : The regression coefficient of lime cost (0.016) was positive and significant at $5 \%$ level for year-round bagda shrimp farming. It indicates that $1 \%$ increase in the cost of lime, keeping other factors constant, would increase gross returns by $0.016 \%$.

Cost of shrimp fry $\left(\mathbf{X}_{6}\right)$ : The estimated coefficient of shrimp fry cost was 0.355 and significant at $1 \%$ level for shrimp farming. It implies that $1 \%$ increase in the cost of shrimp fry, keeping other factors constant, would increase gross returns by $0.355 \%$.

Cost of Fin fish fingerlings $\left(\mathbf{X}_{7}\right)$ : The regression coefficient of fin fish fingerlings cost ($0.007)$ was negative. It indicates that $1 \%$ increase in the cost of fin fish fingerlings, keeping other factors constant, would decrease gross returns by $0.007 \%$. 
Table 4. Estimated values of coefficients and related statistics of Cobb-Douglas production function model for bagda farming

\begin{tabular}{lcc}
\hline \multicolumn{1}{c}{ Explanatory variables } & Coefficients & Standard error \\
\hline Intercept & $4.259^{* * *}$ & 0.420 \\
Cost of urea $\left(\mathrm{X}_{1}\right)$ & $0.109^{* *}$ & 0.081 \\
Cost of TSP $\left(\mathrm{X}_{2}\right)$ & $0.045^{*}$ & 0.045 \\
Cost of manure $\left(\mathrm{X}_{3}\right)$ & $0.218^{* * *}$ & 0.054 \\
Cost of human labor $\left(\mathrm{X}_{4}\right)$ & $0.220^{* * *}$ & 0.061 \\
Cost of lime $\left(\mathrm{X}_{5}\right)$ & $0.016^{*}$ & 0.042 \\
Cost of shrimp fry $\left(\mathrm{X}_{6}\right)$ & $0.355^{* * *}$ & 0.107 \\
Cost of fin fish fingerlings $\left(\mathrm{X}_{7}\right)$ & $-0.007^{*}$ & 0.042 \\
$\mathrm{R}^{2}$ & 0.978 & - \\
Adjusted $\mathrm{R}^{2}$ & 0.975 & - \\
Returns to scale & 0.956 & - \\
F-value & $317.048^{* * *}$ & - \\
\hline
\end{tabular}

* Significant at 10\%; ** Significant at 5\%; ** Significant at $1 \%$

\section{Returns to scale}

The summation of all the production coefficients of bagda farming is equal to 0.956 . This means that production function for bagda farming exhibits diminishing returns to scale (Table 4). However, returns to scale indicates that farm income can be increased if more improved technologies are introduced.

\section{Multiple determinants (R2)}

The coefficient of multiple determinations, $\mathrm{R}^{2}$ for shrimp farming was 0.978 which indicates that 97.8 percent of the total variation of output of respective farming system is explained by independent variables included in the model.

From the Cobb-Douglas production function model, the included key variables of the model were significantly effective on production. So, there is a positive effect of key factors in the production process of year round bagda farming.

\section{CONCLUSION AND POLICY RECOMMENDATIONS}

Shrimp farming in coastal areas needs to be analyzed further as an extension of particular economy. Under the present conditions, it is no doubt, beneficial for a section of people, but it is a matter of great concern for the majority of people. The results however, clearly show that per hectare yield of bagda is still low compared to other shrimp producing Asian countries. There is an ample opportunity to improve per hectare yield of year round bagda shrimp. It may, however, be recommended that scientific method of 
cultivation should be introduced to increase the production. The farmers should be provided with training, information and necessary facilities to cope with new and changed situation. Bank loan and institutional credit should be made available on easy terms and condition to the shrimp farmers. Availability of quality shrimp fry should be ensured at proper time for bagda shrimp farming. Attention should be given to improve transportation and marketing facilities of the study area. Motivation programme should be strengthened in the study area to protect various shrimp and fish fry from destruction during bagda fry collection. Field level agronomic research is suggested to be carried out for studying the impact of salinity on the yield of various crops including vegetables and fruits. Physiological and soil related research should be conducted to study the real causes of die back diseases and bud drop of coconut and date palm trees. Law enforcing agencies should be vigilant in the study area to minimize the social tension and improve the situation of shrimp farming areas. Finally, if more areas could be brought under shrimp cultivation, the country could probably have earned a huge amount of foreign exchange by exporting shrimp.

\section{REFERENCES}

Alam, S. M. N. 2007. "Economic returns of disease-affected extensive shrimp farming in southwest Bangladesh". Journal of Food and Aquatic Science, Curtin University of Technology, Perth, Australia. 15(5): 363-370.

BER, 2007. Bangladesh Economic Review, Department of Finance, Ministry of Finance, Govt. of the People's Republic of Bangladesh, Dhaka, The People's Republic of Bangladesh, Dhaka.

BBS, 2007. "Statistical Year Book of Bangladesh", Bangladesh Bureau of Statistics, Ministry of Planning, Government of the People's Republic of Bangladesh, Dhaka.

BER, 2008. Bangladesh Economic Review, Department of Finance, Ministry of Finance, Govt. of the People's Republic of Bangladesh, Dhaka.

Dillon, J. L. and Hardaker, J. B. 1993. Farm Management Research for Small Farmer Development, FAO, Rome, Italy.

FFYP, 1998. The Fifth Five Year Plan (1997-2002). Planning Commission, Government of the People's Republic Bangladesh, Dhaka.

FSYB, 2007-2008. Fisheries Statistical Yearbook of Bangladesh, Department of Fisheries, Ministry of Fisheries and Livestock, Bangladesh.

Liao, D. S. 1996. The production economics of fresh water shrimp farming in southern Taiwan. Journal of the Fisheries Society of Taiwan, Institute of Fisheries Economics, National Taiwan Ocean University, Keelung, Taiwan, 23: 1, 59-66.

Miah, M. T. H. and Islam, S. 1992. Shrimp farming in Satkhira district of Bangladesh: an economic analysis. Economic Affairs, 37(2): 100-104.

Rosenberry, R. 1998. World Shrimp Farming, Shrimp News International, Sandigo. 